\title{
PEMANFAATAN BAHAN ORGANIK SEBAGAI PEMBAWA UNTUK PENINGKATAN KEPADATAN POPULASI TRICHODERMA VIRIDE PADA RIZOSFIR PISANG DAN PENGARUHNYA TERHADAP PENYAKIT LAYU FUSARIUM
}

\author{
Nurbailis \& Martinius \\ Departemen Hama dan Penyakit Tumbuhan, Fakultas Pertanian Universitas Andalas Padang \\ E-mail: nurbailisjamarun@yahoo.co.id
}

\begin{abstract}
The use of organic matter as carrier for increasing the density of Trichoderma viride in banana rhizosphere and its influence on Fusarium wilt disease development. The aims of the research were to determine the best organic matter as carrier for growth and increasing the density of Trichoderma viride strain $T V$-T1sk (TV-T1sk) and its influence on Fusarium wilt disease development on banana seedling. This research consisted of two experiments, i.e. (1). Growth testing of $T V$-T1sk in various organic matter, (2). Various organic matter testing for increasing the density of $T V$-T1sk in banana rhizosphere and its influence on Fusarium wilt desease development. The treatments were various organic matter, namely rice straw, sugar cane pulp, rice bran+banana plant waste, hull of rice+sugar cane pulp and rice. The variables observed were density and viability of conidia on various organic matter. Propagule density after introduction to banana rhizosphere was determined by observing $T V$-T1sk propagul from the rizosphere of banana seedling. The influence of density on Fusarium wilt disease development was determined by incubation period, the percentage of symptomized leaves and the intensity of corm damage. The results showed that both sugar cane pulp and rice were the best organic matter for increasing the growth and the density of $T V$-T1sk after introduction to banana rhizosphere. The density of $T V$-T1sk propagule on banana rhizophere influenced the development of Fusarium wilt disease.
\end{abstract}

Key word: Fusarium oxysporum f.sp. cubence, density, Fusarium wilt desease, Trichoderma

\begin{abstract}
ABSTRAK
Pemanfaatan bahan organik sebagai pembawa untuk peningkatan kepadatan populasi Trichoderma viride pada rizosfir pisang dan pengaruhnya terhadap penyakit layu Fusarium. Penelitian ini bertujuan untuk mengetahui bahan organik yang terbaik sebagai pembawa untuk pertumbuhan dan peningkatan kepadatan propagul Trichoderma viride strain T1sk (TV-T1sk) pada rizosfir pisang dan pengaruhnya terhadap perkembangan penyakit layu Fusarium. Penelitian terdiri dari dua unit percobaan yaitu 1. Pengujian pertumbuhan $T V$-T1sk yang diperbanyak pada berbagai bahan organik, 2. Pengujian berbagai bahan organik sebagai pembawa untuk peningkatan kepadatan propagul $T V$-T1Sk pada rizosfir pisang dan pengaruhnya terhadap perkembangan penyakit layu Fusarium. Bahan organik yang diuji yaitu jerami padi (A), ampas tebu (B), dedak + sisa tanaman pisang (C), sekam padi + ampas tebu (D) dan beras (E). Peubah yang diamati meliputi kepadatan konidia, daya kecambah konidia, kepadatan propagul pada rizosfir pisang. Pengaruh kepadatan propagul pada rizosfir pisang terhadap perkembangan penyakit layu Fusarium ditentukan dengan mengamati masa inkubasi, persentase daun bergejala dan intensitas kerusakan bonggol. Hasil penelitian menunjukkan ampas tebu dan beras merupakan bahan organik yang terbaik dalam meningkatkan pertumbuhan $T V$-T1SK dan peningkatan kepadatan $T V$-T1SK setelah pada rizosfir pisang. Kepadatan propagul $T V$-T1sk berpengaruh terhadap perkembangan penyakit layu Fusarium. Semakin tinggi kepadatan propagul semakin rendah tingkat serangan penyakit layu Fusarium pada bibit pisang.
\end{abstract}

Kata kunci: Fusarium oxysporum f.sp. cubence, kepadatan, Penyakit layu Fusarium, Trichoderma

\section{PENDAHULUAN}

Penyakit layu Fusarium yang disebabkan oleh Fusarium oxysporum f.sp. cubense (Foc) merupakan salah satu penyakit penting pada tanaman pisang. Penyakit ini sulit dikendalikan karena Foc dapat membentuk klamidospora yang merupakan struktur bertahan jika tidak ada tanaman inangnya, yang mampu bertahan selama lebih dari 30 tahun di dalam tanah (Ploetz, 1990).

Beberapa metode pengendalian yang disarankan untuk pengendalian Foc yaitu penggunaan bibit sehat 
yang berasal dari kultur jaringan, eradikasi dan sanitasi. Pengendalian Foc pada lokasi yang terserang berat hanya dapat dilakukan dengan eradikasi. Cara inipun hanya dapat mematikan pisang sakit dan belum dapat memusnahkan sumber inokulum yang berada dalam tanah (Nasir dan Jumjunidang, 2002).

Salah satu alternatif pengendalian yang memberikan harapan untuk dikembangkan yaitu pengendalian hayati dengan menggunakan jamur antagonis Trichoderma spp. Mekanisme Trichoderma spp. dalam mengendalikan berbagai jenis patogen tanaman dapat dibedakan secara langsung dan tidak langsung terhadap patogen. Menurut Harman (2000), mekanisme secara langsung berupa kompetisi, hiperparasit, antibiosis dan lisis. Harman et al. (2004) melaporkan bahwa mekanisme tidak langsung terhadap patogen diantaranya memperkuat sistem perakaran, meningkatkan pertumbuhan tanaman, meningkatkan ketersediaan hara dan menginduksi ketahanan tanaman.

Keberhasilan Trichoderma spp. untuk pengendalian patogen tanaman telah banyak dilaporkan. Hajieghvari et al. (2008) melaporkan isolat Trichoderma spp. yang berasal dari Iran mampu menghambat pertumbuhan berbagai jenis patogen tular tanah. Isolat T. hamatum T612 merupakan isolat yang paling efektif menghambat pertumbuhan Fusarium graminearum dengan daya penghambatan $48.65 \%$. Yedidia et al. (1999) melaporkan bahwa T. harzianum strain T-203 mampu mengkolonisasi dan bersifat endofit pada akar bibit mentimun yang menyebabkan bibit tahan terhadap serangan patogen.

Diantara Trichoderma spp. yang berasal dari rizosfir tanaman pisang dari beberapa sentra produksi di Sumatera Barat, ada tiga strain yang efektif menekan pertumbuhan Foc secara in planta dan in vitro yaitu Trichoderma koningii strain S6sh ( $T K$-S6sh), Trichoderma harzianum strain S10sh (TH-S10sh) dan Trichoderma viride strain T1sk (TV-T1sk) (Nurbailis, et al., 2006, Nurbailis et al., 2008). Isolat $T V$-T1Sk mempunyai kemampuan kolonisasi $93 \%$ pada akar bibit pisang yang lebih tinggi dibandingkan dengan isolat $T K$ S6sh dan $\mathrm{TH}$-S10sh. Isolat ini juga bersifat endofit pada jaringan akar bibit pisang sehingga efektif menekan penyakit layu Fusarium dan meningkat pertumbuhan tanaman (Nurbailis \& Martinius, 2009). Kepadatan populasi isolat $T V$-T1 sk setelah diintroduksikan ke dalam tanah belum diketahui.

Salah satu kendala dalam pemanfaatan Trichoderma sebagai agens pengendali hayati yaitu rendahnya kemampuan adaptasi dan perkembangan populasi pada rizosfir setelah diintroduksikan ke dalam tanah. Menurut Sinaga (1989) agens hayati sebelum diintroduksikan ke dalam tanah sebaiknya diperbanyak secara massal pada bahan organik yang sesuai untuk pertumbuhan dan perkembangan agar dapat beradaptasi pada lingkungan yang baru setelah diintroduksikan ke dalam tanah. Kemampuan beradaptasi dan perkembangan Trichoderma pada ekosistem pertanaman sangat menentukan dalam keberhasilan pengendalian penyakit tanaman yang berkelanjutan. Jayasuriya and Thennakoon (2007) melaporkan bahwa medium campuran pupuk kandang dan dedak padi (1:1) dapat meningkatkan kepadatan populasi Trichoderma isolat Srilanka (T310) dibanding dengan campuran substrat lainnya. Viabilitas dari T310 dapat bertahan lebih dari 20 minggu setelah diintroduksikan ke dalam tanah dan efektif menekan penyakit akar putih yang disebabkan oleh Rigidiporus lignosus pada karet. Lewis dan Papavizas (1984) melaporkan bahwa T. harzianum dan T. viride yang dibiakkan pada campuran sekam, pasir dan air $(1: 1: 1, \mathrm{~b} / \mathrm{b} / \mathrm{v})$ selama tiga hari sebelum diintroduksikan ke dalam tanah, menunjukkan peningkatan populasi kedua agen antagonis tersebut hingga $10^{4}$ dan $10^{3}$ kali selama tiga minggu pertama inkubasi. Peningkatan populasi tidak terjadi apabila yang diintroduksikan ke dalam tanah dalam bentuk konidia atau konidia dengan subsratnya.

Substrat atau bahan organik sebagai makanan dasar dan pembawa jamur antagonis berpengaruh terhadap daya adaptasi dan peningkatan kepadatan populasinya setelah diintroduksikan ke dalam tanah. Menurut Weaver et al. (2005) propagul jamur antagonis yang memiliki persistensi yang tinggi akan mempunyai peluang yang besar untuk bisa kontak dengan jamur patogen sehingga pertumbuhan dan perkembangan patogen terhambat. Syatrawati (2008) melaporkan, untuk menghasilkan konidia jamur antagonis dipengaruhi oleh kualitas substrat sebagai medium pertumbuhannya yang berkaitan dengan nutrisi yang terkandung dalam substrat tersebut. Menurut Singhania (2006), jamur Trichoderma sp. merupakan jamur selulotik yang potensial mendegradasi bahan organik yang mengandung selulosa untuk pertumbuhannya. Medium perbanyakan yang biasa digunakan petani untuk aplikasi Trichoderma di lapangan yaitu beras (survey lapangan), namun pemanfaatan beras untuk perbanyakan Trichoderma membutuhkan biaya yang cukup tinggi dan bersaing dengan kebutuhan manusia. Untuk itu diperlukan alternatif bahan perbanyakan Trichoderma berupa bahan organik lainnya sehingga dapat meningkat daya adaptasi dan perkembangannya setelah diintroduksikan dan efektif dalam pengendalian patogen tanaman. 
Bahan organik memiliki nutrisi yang dibutuhkan oleh jamur untuk pertumbuhan dan perkembangannya. Menurut Husin (2007) nutrisi yang terkandung dalam limbah organik ampas tebu yaitu abu $3,82 \%$, selulosa $37,65 \%$, sari $1,81 \%$, pentosan $27,97 \%$, dan $\mathrm{SiO}_{2} 3,01 \%$, jerami yaitu serat $67 \%$, abu $35,15 \%$, lemak 3,14 dan protein kasar 7,80\% dan dedak yaitu 16,2\% air, 9,5\% protein, 43,8\% serat kasar, 3,3\% lemak dan $10.8 \%$ abu. Manglayang (2006) melaporkan bahan organik berupa sekam mengandung $11,5 \%$ air, 20,03\% abu, lignin $35,53 \%$ dan $22-30,71 \%$ selulosa.

Tujuan dari penelitian ini adalah untuk mengetahui bahan organik terbaik sebagai pembawa $T V$-T1Sk untuk peningkatan kepadatan populasi setelah diintroduksikan pada rizosfir pisang dan pengaruhnya terhadap perkembangan penyakit layu Fusarium pada bibit pisang.

\section{METODE PENELITIAN}

Tempat dan Waktu. Penelitian dilaksanakan di Laboratorium Fitopatologi Jurusan Hama dan Penyakit Tumbuhan Fakultas Pertanian Universitas Andalas Padang dan rumah kaca Fakultas Pertanian Universitas Andalas mulai April sampai Oktober 2010.

Rancangan. Penelitian terdiri dari dua unit percobaan yaitu (1) pengujian pertumbuhan $T V$-T1Sk yang diperbanyak dalam berbagai limbah organik dan (2) Pengujian berbagai bahan organik sebagai pembawa untuk peningkatan kepadatan populasi $T V$-T1Sk pada rizosfir dan pengaruhnya terhadap perkembangan penyakit layu Fusarium. Percobaan pertama menggunakan Rancangan Acak Lengkap (RAL) dengan 5 perlakuan dan 5 ulangan. Percobaan kedua menggunakan Rancangan Acak Kelompok (RAK) dengan 5 perlakuan dan 5 ulangan tiap ulangan terdiri dari 3 tanaman. Perlakuannya adalah berbagai limbah organik untuk perbanyakan $T V$-T1sk yang terdiri dari jerami padi (A), ampas tebu (B), dedak + sisa tanaman pisang (C), sekam padi +ampas tebu (D) dan beras (E). Data diolah dengan menggunakan Program Statistik 8.

Perbanyakan Strain Trichoderma viride Strain T1Sk (TV-T1Sk). Trichoderma viride strain T1Sk (TVT1Sk) merupakan isolat yang didapatkan dari rizosfir tanaman pisang yang menunjukkan gejala penyakit layu Fusarium di Kabupaten Tanah Datar Provinsi Sumatera Barat (Nurbailis et al., 2008), isolat tersebut telah dikoleksi di Laboratorium Fitopatologi Fakultas Pertanian Universitas Andalas Padang. Untuk keperluan penelitian isolat ini diremajakan selama 6 hari pada suhu ruang.
Persiapan dan Perbanyakan Strain TV-T1sk pada Limbah Organik. Limbah organik berupa jerami padi, ampas tebu, dan sisa tanaman pisang dipotong -potong dengan ukuran lebih kurang $1 \mathrm{~cm}$ dan dilembabkan. Sekam padi dan dedak halus langsung dilembabkan. Beras dimasak setengah matang kemudian dimasukkan ke dalam kantong plastik dan disterilkan menggunakan autoklaf selama $1 \mathrm{jam}$. Setelah dingin diinokulasi dengan potongan biakan strain $T V$-T1 sk yang berdiameter $1 \mathrm{~cm}^{2}$ selanjutnya diinkubasi 15 hari.

Perbanyakan Fusarium oxysporum f.sp. cubense (Foc). Jamur Foc yang sudah dikoleksi di Laboratorium Fitopatologi HPT Faperta Universitas Andalas di reisolasi dalam medium PDA dan diinkubasi 10 hari. Foc diperbanyak dalam medium beras sebagai bahan inokulum untuk diinokulasikan pada bibit pisang.

Persiapan Tanah. Tanah yang digunakan adalah jenis ultisol yang berasal dari kebun percobaan Fakultas Pertanian Universitas Andalas. Tanah dicampur dengan pupuk kandang dengan perbandingan 2:1 kemudian disterilkan. Tanah tersebut dimasukkan ke dalam polibag sebanyak $6 \mathrm{~kg}$ setiap polybag.

Persiapan Bibit Pisang. Bibit pisang yang digunakan adalah jenis Barangan yang merupakan bibit kultur jaringan yang telah diaklimatisasi selama satu bulan yang diperoleh dari Balai Penelitian Buah Tropika Solok. Bibit ditempatkan di rumah kaca Fakultas Pertanian Universitas Andalas.

Perlakuan Tanah dan Penanaman Bibit Pisang. Strain $T V$-T1Sk yang telah diperbanyak dalam berbagai limbah organik dicampurkan dengan medium tanam sebanyak $9 \mathrm{~g} / \mathrm{kg}$ tanah. Biakan Trichoderma tersebut dicampur sampai kedalaman $15 \mathrm{~cm}$ dari permukaan tanah dalam polibag, kemudian diinkubasi selama 7 hari. Selanjutnya bibit pisang ditanam 1 batang setiap polibag.

Inokulasi Fusarium oxysporum f.sp. cubense (Foc). Inokulasi Foc dilakukan pada saat tanaman berumur 14 hari dengan membuat lubang disekeliling bibit sedalam $5 \mathrm{~cm}$, dengan jarak $2 \mathrm{~cm}$ dari pangkal bibit. Setelah itu, biakan Foc dalam media beras diinokulasikan ke dalam lubang tersebut sebanyak $10 \mathrm{~g} / \mathrm{bibit}$ dan ditimbun kembali dengan tanah.

Pemeliharaan. Pemeliharaan dilakukan dengan menyiram tanaman sesuai dengan kebutuhan bibit, gulma yang tumbuh disiang dengan cara pencabutan. 


\section{Variabel Pengamatan}

Kepadatan Konidia. Kepadatan konidia strain $T V$ T1Sk yang diperbanyak dalam limbah organik dihitung dengan cara mengambil $1 \mathrm{~g}$ biakan $T V$-T1Sk yang telah diinkubasi selama 15 hari pada limbah organik, kemudian dicampur dengan $10 \mathrm{ml}$ aquades steril dan dihomogenkan dengan vortex kemudian disaring dengan kain kasa. Selanjutnya dibuat suspensi konidia sampai pengenceran $10^{-4}$, penghitungan konidia dilakukan di bawah mikroskop dengan menggunakan haemocytometer.

Daya Kecambah Konidia. Daya kecambah konidia ditentukan dengan menggunakan slide culture. Medium PDA dengan luas sekitar $1 \mathrm{~cm}^{2}$ dan tebal 1-2 mm diletakkan di atas gelas objek steril. Di atas medium diteteskan $10 \mu \mathrm{l}$ suspensi konidia yang mengandung $10^{6}$ konidia/ml dari masing-masing $T V$-T 1 sk yang diperbanyak dalam limbah organik. Gelas objek tersebut ditempatkan pada cawan petri yang steril yang telah dilapisi kertas saring lembab, setelah itu diinkubasi selama 18 jam pada suhu ruang dan diamati di bawah mikroskop. Konidia dinyatakan berkecambah apabila tabung kecambah telah melebihi diameter konidia.

\section{Kepadatan Propagul Trichoderma viride strain TV-}

T1Sk. Kepadatan $T V$-T1Sk diamati dengan cara menghitung propagul $T V$-T1Sk dari tanah rizosfir pertanaman pisang, dengan metode cawan tuang. Pengamatan dilakukan dengan cara mengambil tanah di sekitar rizosfer pertanaman pisang sebanyak $10 \mathrm{~g}$ kemudian diambil $1 \mathrm{~g}$ dari tanah tersebut ditambahkan dengan $10 \mathrm{ml}$ aquades dan dibuat pengenceran sampai $10^{-4}$. Suspensi dari pengenceran $10^{-4}$ diambil $1 \mathrm{ml}$ dan dimasukkan ke dalam cawan petri dan ditambah dengan $9 \mathrm{ml}$ medium McFadden \& Sutton yang merupakan medium selektif untuk pertumbuhan Trichoderma (McFadden \& Sutton RB-S-F medium, 1975). Pengamatan dilakukan pada hari kedua setelah inokulasi sampai cawan petri penuh. Propagul dihitung dengan menggunakan rumus Herr (1959) cit. Habazar et at., (1989) $\mathrm{A}=(\mathrm{K}(100+\mathrm{KA}) \mathrm{xP}) / 100$ dengan $\mathrm{A}=$ jumlah propagul/gram bahan, $K=$ jumlah propagul
Trichoderma/petri, KA = kadar air bahan, dan $\mathrm{P}=$ Pengenceran

Masa Inkubasi (hari). Masa inkubasi diamati berdasarkan munculnya gejala pertama yang dilakukan setiap hari setelah inokulasi Foc sampai tanaman berumur 60 hari.

Persentase Daun Bergejala. Persentase daun bergejala diamati dengan menghitung jumlah daun bergejala pada setiap tanaman. Pengamatan dimulai dari munculnya gejala pertama sampai tanaman berumur 60 hari dengan interval 7 hari. Persentase daun bergejala dihitung dengan menggunakan rumus $\mathrm{Pd}=\mathrm{c} / \mathrm{d} \times 100 \%$ dengan $\mathrm{Pd}=$ persentase daun bergejala, $\mathrm{c}=$ jumlah daun bergejala per tanaman, dan $\mathrm{d}=$ jumlah daun keseluruhan per tanaman.

Intensitas Kerusakan Bonggol. Pengamatan kerusakan bonggol dilakukan saat akhir pengamatan. Perhitungan skoring kerusakan bonggol dilakukan dengan metode yang dikembangkan Internationl Network for the Improvement of Banana and Plantain (INIBAP, 1998) seperti Tabel 1.

Intensitas kerusakan bonggol dihitung dengan menggunakan rumus Ds $=\left("\left(\mathrm{n}_{1} \times \mathrm{V}_{1}\right) /(\mathrm{Z} \times \mathrm{N})\right) \times 100 \%$ dengan Ds $=$ intensitas $\operatorname{kerusakan}(\%), \mathrm{n}_{1}=$ jumlah bonggol yang terserang pada setiap kategori, $\mathrm{V}_{1}=$ jumlah sampel masing-masing kategori serangan, $\mathrm{Z}=$ nilai kategori serangan tertinggi, dan $\mathrm{N}=$ jumlah batang semu yang diamati

\section{HASIL DAN PEMBAHASAN}

Kepadatan Konidia $T V$-T1Sk pada Berbagai Bahan Organik. Kepadatan konidia strain $T V$-T1Sk yang diperbanyak pada berbagai bahan organik berbeda nyata antar perlakuan (Tabel 2). Kepadatan konidia pada bahan organik beras tidak berbeda nyata dengan yang terdapat pada ampas tebu $\left(20,0 \times 10^{8}\right.$ dan $18,5 \times 10^{8}$ konidia/ml). Kepadatan konidia pada kedua bahan

Tabel 1. Kriteria skoring keru sakan bonggol pada tanaman pisang

\begin{tabular}{lc}
\hline \multicolumn{1}{c}{ Gejala } & Skoring \\
\hline Tidak ada bintik hitam pada jaringan bonggol & 1 \\
Ada beberapa bintik hitam pada bongg ol & 2 \\
Ada bintik hitam menu tupi $<1 / 3$ dari jaringan bonggol & 3 \\
Ada bintik hitam menutupi $1 / 3-2 / 3$ dari jaringan bonggol & 4 \\
Ada bintik hitam menu tupi $>2 / 3$ dari jaringan bonggol & 5 \\
Terdapat bintik hitam pada seluruh jaringan bonggol & 6 \\
\hline
\end{tabular}


organik ini lebih tinggi dibanding dengan yang terdapat pada bahan organik lainnya. Tingginya kepadatan konidia pada beras dan ampas tebu disebabkan kedua bahan ini megandung nutrisi yang diperlukan oleh Trichoderma untuk pertumbuhan dan perkembangannya. Secara umum Trichoderma akan tumbuh baik pada medium yang mengandung karbohidrat dan sellulosa yang tinggi. Menurut Syatrawati (2008) untuk menghasilkan konidia jamur antagonis dipengaruhi oleh kualitas substrat sebagai medium pertumbuhannya yang berkaitan dengan nutrisi yang terkandung dalam substrat tersebut. Menurut Singhania et al. (2006), jamur Trichoderma sp. merupakan jamur sellulotik yang potensial mendegradasi bahan organik yang mengandung selulosa untuk pertumbuhannya.

Daya Kecambah Konidia $T V$-T1Sk yang Diperbanyak pada Berbagai Medium Organik. Daya kecambah konidia $T V$-T1sk yang diperbanyak pada berbagai medium organik menunjukkan hasil yang berbeda nyata (Tabel 3). Daya kecambah konidia TVT1sk yang diperbanyak pada bahan organik ampas tebu tidak berbeda nyata dengan yang diperbanyak pada medium beras yaitu $93,2 \%$ dan 90,2\%. Daya kecambah konidia pada kedua bahan organik ini lebih tinggi dibandingkan dengan bahan organik lainnya. Hal ini berhubungan dengan kepadatan konidia $T V-T 1 s k$ yang dibiakkan pada berbagai bahan organik (Tabel 2). Kepadatan konidia yang tinggi pada medium beras dan ampas tebu menunjukkan pertumbuhan dan perkembangan $T V-T 1 s k$ pada medium tersebut sangat baik, yang juga diikuti oleh tingginya daya kecambah konidia $T V-T 1 s k$ yang dibiakkan pada kedua medium tersebut. Daya kecambah konidia yang terendah terdapat pada $T V$-T1sk yang diperbanyak pada dedak + sisa tanaman pisang yaitu $65,6 \%$ yang tidak berbeda nyata dengan $T V$-T1sk yang diperbanyak pada limbah organik jerami padi yaitu $71,0 \%$.

Pertumbuhan dan perkembangan $T V$-T1Sk yang diperbanyak dalam berbagai bahan organik menunjukkan beras dan ampas tebu merupakan bahan organik yang terbaik untuk meningkatkan pertumbuhan dan perkembangan strain $T V$-T1Sk. Hal ini dapat dilihat dengan tingginya kepadatan konidia dan daya kecambah strain $T V$-T1sk yang diperbanyak pada bahan organik tersebut (Tabel 2 dan 3)

Perbedaan pertumbuhan dan perkembangan strain $T V$-T1sk yang dibiakkan pada berbagai bahan organik disebabkan karena kandungan nutrisi dari limbah organik tersebut berbeda-beda. Secara umum Trichoderma memerlukan bahan yang mengandung karbohidrat dan sellulosa untuk pertumbuhannya. Menurut Husin (2007) kandungan sellulosa dari ampas tebu mencapai 37, 65\%, sedangkan pada jerami kandungan yang tertinggi yaitu

Tabel 2. Kepadatan konidia strain $T V$-T1Sk pada berbagai bahan organik umur 15 hari setelah inokulasi

\begin{tabular}{lc}
\hline \multicolumn{1}{c}{ Jenis Bahan Organik } & Kepadatan Konidia/ml Aquades \\
\hline Beras & $20,0 \times 10^{8} \mathrm{a}$ \\
Ampas tebu & $18,5 \times 10^{8} \mathrm{ab}$ \\
Sekam + ampas tebu & $16,1 \times 10^{8} \mathrm{bc}$ \\
Dedak + sisa tanaman pisang & $15,0 \times 10^{8} \mathrm{c}$ \\
Jerami padi & $11,7 \times 10^{8} \mathrm{~d}$ \\
\hline Anga-anga
\end{tabular}

Angka-angka yang diikuti huruf yang sama tidak berbeda nyata menurut uji Duncan ( $>0,05)$.

Tabel 3. Persentase daya kecambah konidia $T V$-T1Sk pada berbagai bahan organik 18 jam setelah isolasi

\begin{tabular}{lc}
\hline \multicolumn{1}{c}{ Perlakuan } & Persentase Daya Kecambah Konidia \\
\hline Ampas tebu & $93,2 \mathrm{a}$ \\
Beras & $90,2 \mathrm{a}$ \\
Sekam + ampas tebu & $83,6 \mathrm{~b}$ \\
Jerami padi & $71,0 \mathrm{c}$ \\
Dedak + sisa tanaman pisang & $65,6 \mathrm{c}$ \\
\hline
\end{tabular}

Angka-angka yang diikuti huruf yang sama tidak berbeda nyata menurut uji Duncan ( $p>0,05)$. 
serat yang mencapai 67\%. Manglayang (2006) melaporkan bahan organik berupa dedak mengandung serat kasar sebesar 43,8\%. Kandungan sellulosa pada sekam padi cukup tinggi yaitu $22-30,71 \%$ tetapi ligninnya juga tinggi yaitu $35,53 \%$ sehingga sulit didegradasi oleh Trichoderma. Kandungan selulosa limbah organik sangat mempengaruhi pertumbuhan $T V$-T1sk, ampas tebu dengan kandungan sellulosa yang cukup tinggi dapat meningkatkan pertumbuhan dan daya kecambah konidia isolat tersebut dibandingkan dengan limbah organik lainnya.

\section{Kepadatan Propagul TV-T1Sk setelah Diintroduksikan ke dalam Tanah dan Pengaruhnya terhadap Penyakit Layu Fusarium pada Bibit} Pisang. Kepadatan propagul $T V$-T1Sk yang diperbanyak pada berbagai bahan organik 75 hari setelah diintroduksikan pada rizosfir pisang menunjukkan hasil yang berbeda nyata (Tabel 4). Kepadatan propagul $T V$ T1Sk pada rizosfir pisang yang paling tinggi terdapat pada $T V$-T1sk yang diperbanyak dalam medium beras yaitu $65,57 \times 10^{4} \mathrm{cfu} / \mathrm{g}$ tanah yang tidak berbeda nyata dengan yang diperbanyak pada bahan organik ampas tebu yaitu $63,31 \times 10^{4} \mathrm{cfu} / \mathrm{g}$ tanah tetapi berbeda nyata dengan limbah organik lainnya

Kepadatan propagul $T V$-T1sk yang diperbanyak pada bahan organik beras tidak berbeda nyata dengan medium organik ampas tebu, 75 hari setelah diintroduksikan pada rizosfir pisang. Hal ini disebabkan kepadatan dan daya kecambah konidia pada kedua bahan organik ini lebih tinggi dari limbah organik lainnya (Tabel 2 dan 3). Setelah diintroduksikan ke dalam tanah agensia antagonis ini mampu beradapatasi dengan lingkungan yang baru sehingga dapat tumbuh dan berkembang dengan baik di tanah rizosfir pisang.
Menurut Sinaga (1989), agens hayati sebelum diintroduksikan ke dalam tanah sebaiknya diperbanyak secara massal pada bahan organik yang sesuai untuk pertumbuhan dan perkembangan agar dapat beradaptasi pada lingkungan yang baru setelah diintroduksikan. Jayasuriya and Thennakoon (2007) melaporkan bahwa pupuk kandang dan dedak padi (1:1) dapat meningkatkan pertumbuhan dan perkembangan Trichoderma isolat Srilanka (T310) dibanding dengan campuran substrat lainnya. Viabilitas dari T310 dapat bertahan lebih dari 20 minggu setelah diintroduksikan. Pada penelitian ini, perlakuan campuran dedak dan sisa tanaman pisang memperlihatkan persistensi yang paling rendah. Hal ini disebabkan sisa tanaman pisang tidak cocok sebagai medium perbanyakan Trichoderma.

Kepadatan propagul $T V$-T1Sk 75 hari setelah diintroduksikan ke dalam tanah (rizosfir pisang) berpengaruh terhadap penekanan penyakit layu Fusarium terutama terhadap persentase daun bergejala dan intensitas kerusakan bonggol tetapi tidak berpengaruh terhadap masa inkubasi. Kepadatan propagul $T V$-T1sk yang telah diperbanyak pada berbagai bahan organik tidak berpengaruh terhadap masa inkubasi Fusarium pada bibit pisang karena $T V$-T1sk yang diintroduksikan pada rizosfir pisang mememerlukan waktu untuk beradaptasi sehingga sampai 3 minggu setelah introduksi $T V$-T1sk belum mampu melindungi bibit pisang terhadap infeksi Fusarium.

Kepadatan propagul $T V$-T1sk berpengaruh terhadap persentase daun bergejala dan intensitas kerusakan bonggol. Strain TV-T1sk yang tumbuh dan berkembang pada rizosfir pisang dapat menghambat kontak antara patogen dengan inangnya. Menurut Weaver et al. (2005), propagul jamur antagonis yang memiliki persistensi yang tinggi akan mempunyai peluang

Tabel 4. Kepadatan propagul Trichoderma viride strain $T V$-T1sk 75 hari setelah diintroduksi ke dalam tanah dan pengaruhnya terhadap perkembangan penyakit layu Fusarium pada bibit pisang

\begin{tabular}{lcccc}
\hline $\begin{array}{c}\text { Jenis Bahan } \\
\text { Organik }\end{array}$ & $\begin{array}{c}\text { Kepadatan Propagul } \\
\text { (cfu/g bahan) }\end{array}$ & $\begin{array}{c}\text { Masa Inkubasi } \\
\text { (hari) }\end{array}$ & $\begin{array}{c}\text { Daun } \\
\text { Bergejala }(\%)\end{array}$ & $\begin{array}{c}\text { Intensitas Kerusakan } \\
\text { Bonggol (\%) }\end{array}$ \\
\hline Beras & $6,56 \times 10^{5} \mathrm{a}$ & $24,38 \mathrm{a}$ & $30,57 \mathrm{c}$ & $22,95 \mathrm{c}$ \\
Ampas tebu & $6,33 \times 10^{5} \mathrm{a}$ & $23,06 \mathrm{a}$ & $27,42 \mathrm{c}$ & $34,80 \mathrm{c}$ \\
Jerami padi & $4,73 \times 10^{5} \mathrm{~b}$ & $22,06 \mathrm{a}$ & $40,25 \mathrm{ab}$ & $39,25 \mathrm{ab}$ \\
$\begin{array}{l}\text { Sekam + ampas } \\
\text { tebu }\end{array}$ & $4,39 \times 10^{5} \mathrm{~b}$ & $19,9 \mathrm{a}$ & $42,61 \mathrm{a}$ & $45,55 \mathrm{a}$ \\
$\begin{array}{l}\text { Dedak + sisa } \\
\text { tanaman pisang }\end{array}$ & $4,32 \times 10^{5} \mathrm{~b}$ & $20,66 \mathrm{a}$ & $42,96 \mathrm{a}$ & $43,32 \mathrm{a}$ \\
\hline
\end{tabular}

Angka-angka pada lajur yang diikuti oleh huruf kecil yang sama tidak berbeda nyata menurut uji Duncan $(p>0,05)$. 
yang besar untuk bisa kontak dengan jamur patogen sehingga pertumbuhan dan perkembangan jamur terhambat (Weaver et al., 2005). Hasil penelitian Nurbailis et al. (2008) menunjukkan strain TV-T1sk bersifat antagonis terhadap Foc secara in vitro yang meliputi kompetisi, hiperparasit dan antibiosis. Menurut Harman (2000) mekanisme Trichoderma spp. dalam mengendalikan berbagai patogen tanaman dapat berupa kompetisi, hiperparasit, antibiosis dan lisis .

Introduksi $T V$-T1sk yang dibiakkan pada bahan organik beras dan ampas tebu memiliki kepadatan propagul yang lebih tinggi dibanding dengan yang dibiakkan pada bahan organik lainnya. Hal ini berpengaruh terhadap persentase daun bergejala dan intensitas kerusakan bonggol pada bibit pisang. Strain $T V$-T1Sk yang dibiakkan pada ampas tebu dan beras dapat memproduksi jumlah konidia dan mempunyai daya kecambah lebih tinggi dari pada yang dibiakkan pada bahan organik lainnya (Tabel 1 dan 2), sehingga setelah diintroduksikan ke dalam tanah jamur tersebut mempunyai daya viabilitas yang tinggi di dalam tanah dan mampu bersaing dengan Fusarium yang mengakibatkan pertumbuhan patogen menjadi terhambat. Jayasuriya and Thennakoon (2007) melaporkan Trichoderma isolat Srilanka (T310) yang diperbanyak dalam medium campuran pupuk kandang dan dedak padi $(1: 1)$ dapat meningkat kepadatan konidianya sampai 20 minggu setelah diintroduksikan ke dalam tanah dan efektif menekan penyakit akar putih yang disebabkan oleh Rigidiporus lignosus pada karet.

\section{SIMPULAN}

Bahan organik ampas tebu dan beras merupakan yang terbaik dalam meningkatkan pertumbuhan dan perkembangan $T V$-T1SK. Bahan organik ini juga terbaik dalam peningkatan kepadatan $T V$-T1SK setelah diintroduksikan pada rizosfir pisang. Kepadatan propagul $T V$-T1sk berpengaruh terhadap perkembangan penyakit layu Fusarium. Semakin tinggi kepadatan konidia semakin rendah tingkat serangan penyakit layu Fusarium pada bibit pisang.

\section{SANWACANA}

Melalui kesempatan ini penulis menyampaikan penghargaan dan terima kasih kepada Direktorat Jenderal Pendidikan Tinggi, Departemen Pendidikan Nasional, sesuai dengan Surat Perjanjian Pelaksanaan Pekerjaan Penelitian No: 003/H.16/PL/HB -MT/III/ 2010 tanggal 4 Maret 2010 yang telah membantu pendanaan penelitian ini sehingga penelitian ini dapat berjalan dengan lancar.

\section{DAFTAR PUSTAKA}

Habazar T, Trizelia \& Busniah N. 1989. Pengaruh pemakaian pestisida yang intensif terhadap kehidupan mikroorganisme antagonis dari beberapa patogen dalam tanah. Laporan penelitian operational dan maintenance. Pusat Penelitian Universitas Andalas Padang.

Hajieghvari B, Torabi-Giglou M, Mohamadi MR \& Davari M. 2008. Biological potential of some Iranian Trichoderma Isolates in the control of soil borne plant pathogenic Fungi. African Jurnal of Biotehnology 7 (8):967-972.

Harman GE. 2000. Changes in perceptions derived from research on Trichoderma harzianum T-22. Plant Disease 84 (4):377-392.

Harman GE, Howell CR, Viterbo A, Chet I \& Lorito M. 2004. Trichoderma species: Opportuninistic avirulent plant symbionts. Nature Review/ microbiology 2:43-56.

Husin. 2007. Analisis Serat Bagas. http:// www.free.vlsm.org. Diakses pada 26 Februari 2010.

INIBAP. 1988. Evaluation of musa germplasm for resistance to sigatoka diseases and Fusarium wilt. Prances. International Plant Genetic Resources Institute.

Jayasuriya KE \& Thennakoon BI. 2007. Biological control of Rigidoporos microporus, the cause of white root desease in Rubber. Cey. J. Sci (Bio.Sci) 36 (1):9-16.

Lewis JA \& Papavizas GC. 1984. A new approach to stimulate population proliferation of Trichoderma species and either potential biocontrol fungi introduced into natural soil. Phytopathology 74 :1240-1244.

Manglayang. 2006. Bahan makanan penguat (konsentrat). http:// manglayang. blogsome.Com/ 2005/12/17/proksimat-pakan-ternak-dan-serbaserbi konsentrat. Diakses pada 26 Februari 2010

Nasir N \& Jumjunidang. 2002. Strategi jangka pendek menahan laju perluasan serangan penyakit layu pisang. Makalah disampaikan pada seminar 
nasional pengendalian penyakit layu pisang di Padang.

Nurbailis, Mardinus, Habazar T, Nasril N \& Dharma A. 2006. Penapisan isolat Trichoderma yang berasal dari rizosfir tanaman pisang di Sumatera Barat untuk pengendalian penyakit layu Fusarium. Jurnal Akta Agrosia 9 (1):49-55.

Nurbailis, Mardinus, Habazar T, Nasril N \& Dharma A. 2008. Penapisan Trichoderma spp dari Rizosfir pisang untuk menekan pertumbuhan Fusarium oxysporum f.sp.cubense in vitro. Jurnal Manggaro 10 (2):16-19.

Nurbailis \& Martinius. 2009. Pengendalian Fusarium oxysporum f.sp.cubense penyebab penyakit layu Fusarium pada pisang dengan Trichoderma spp. indigenus rizosfir pisang. Laporan Hibah Bersaing DP2M Dikti.

Ploetz RC. 1990. Vascular wilt disease: Panama disease of bananas. in Fusarium Wilt of Banana. APS Press, St Paul.

Syatrawati. 2008. Produksi senyawa biofungisida berbahan aktif Gliocladium sp. pada berbagai medium limbah organik. http://bdpunib.org/jipi/ artikeljipi/edkhus2/386.pdf. Diakses pada 11 Oktober 2009.

Sinaga MS. 1989. Potensi Gliocladium spp. sebagai agen pengendalian hayati beberapa cendawan patogenik tumbuhan yang bersifat soil borne. Laporan penelitian SPP/DPP FAPERTA IPB 1987/1988. Jurusan Hama dan Penyakit Tumbuhan. Fakultas Pertaian Institut Pertanian Bogor.

Singhania RR. 2006. Solid State fermentation of lignocellulosic substrates for cellulase production by Trichoderma reesei NRRL 11460. Departement of Agriculture and Chemical Technologi University of Budapest. Hungary. Vol 5.

Yedidia I, Benhamou N \& Chet I. 1999. Induction of defence responces in Cucumber plants (Cucumis sativus, L) by the biocontrol agens Trichoderma harzianum. Appl Environ Microbiol. 65 (3):1061-1070.

Weaver MA, Vedenyapina E \& Kenerly CM. 2005. Fitness, persistence, and responsiveness of a genetically engineered strain of Trichoderma virens in soil mesocosms. Applied Soil Ecology 29:125-134. 